\title{
LAND USE IN THE TROPICAL KARST - THE CASE OF PERUAÇU, JANUÁRIA AND JAIBA; SE BRAZIL ${ }^{1}$
}

Heinz Charles Kohler, Sergio dos Anjos Ferreira Pinto and João Francisco de Abreu

\begin{abstract}
The karstic regions of the municipalities of Peruaçu, Januária and Jaiba present a variety of soil uses which are a function of the organization of the karstic relief. This relief system forms a rift, which received fluvial sediments deposition from the São Francisco River.

The horst of the Peruaçu plateau is developed on limestone rocks of Late Proterozoic age with a high concentration of calcium carbonate. The South American Surface was formed on this and is today occupied by cattle ranching.

In the graben, due to easy irrigation from underground karst waters and because of the nearby drainage system of the São Francisco River, a mechanized and specialized farming system has developed.

The change in the management of cattle breeding and in traditional farming methods has had a substantial impact on the economic structure of the community and also on the karst itself.
\end{abstract}

KEY WORDS: Brazil, land use, human impact

\section{Introduction}

Brazil's continental area of approximately 8,5 million square kilometers, between the parallels $6^{\circ} 16^{\prime}$ lat. $\mathrm{N}$ and $33^{\circ} 45^{\prime}$ lat. S, presents different karstic systems due to lithological and hydrological differences (over a wide climatic range). Because of their extent and importance, the karstic scenarios which developed over calcite and dolomite rocks of Late Proterozoic are prominent. The main karstic landscapes are located on Craton de São Francisco, in the surrounding areas in the states of Minas Gerais, Bahia and Goiás, and also in the Arc of Borborema, in the states of Mato Grosso do Sul and Mato Grosso.

The limestone outcrops make up approximately $5 \%$ to $7 \%$ of the total area of the country (Karmann, 1994). If covered karst is included, this percentage would increase considerably. In areas of superficial karst, there is a variation between fluvio-karstic scenarios, sink hole plains, raised plateaus, residual hills, poljes, and large fluvial plains.

\footnotetext{
${ }^{1}$ This research was supported by FAPEMIG (Fundação de Amparo à Pesquisa do Estado de Minas Gerais) Grant - CEX 230596.
} 


\section{The Karst}

The municipal districts of Peruaçu, Januária and Jaiba, are located in the extreme north of Minas Gerais State, about $620 \mathrm{~km}$ away from the state capital, Belo Horizonte. The region is drained by the São Francisco River and its medium sized tributaries.

Climatic analysis done over a period of thirty years (EPAMIG et al., 1976), shows an average precipitation of $876 \mathrm{~mm}$ per year, concentrated in the months of November to April while there are six almost dry months, from May to October. Rainfall is variable and can range from $1400 \mathrm{~mm}$ to $450 \mathrm{~mm}$, depending on the season. The month of October is the hottest $\left(34^{\circ} \mathrm{C}\right)$ and the coldest is July $\left(16^{\circ} \mathrm{C}\right)$, with a thermal average of $24^{\circ} \mathrm{C}$.

The karst has developed in a lens of sub-horizontal meta-sedimentary limestone approximately $350 \mathrm{~m}$ thick, from the Late Proterozoic Bambui Group (Dardenne, 1981). Dissolved carbonate hardness, ranges between 135 ppm and 140 ppm (Pilo, 1989):

The regional stratigraphic column reveals six main units. The mineralogical analysis from X-ray difractometry and their relative percentages, were obtained by Campos et al. (1992):

1) Pink yellowish dolomite limestone;

2) Light grayish calcite;

3) Pinkish dolomite (calcium carbonate $=30 \%$; dolomite $=65.8 \%$ );

4) Yellowish sublitographic dolomite;

5) Siltstones and argillites;

6) Black limestones ( calcium carbonates $=90 \%$; dolomites $=7 \%$ ).

Cretaceous silicified sandstones have reworked the rocks from the Late Proterozoic.

Piló (1989) studied the Karst of the Peruaçu River region, a tributary of the left margin of the São Francisco River: there are six principal morphological units.

A. Covered karst constituted of two surfaces:

a) residual hills of a Cretaceous surface with a duricrust, above the level of $780 \mathrm{~m}$ and reaching $800 \mathrm{~m}$.

b) The South American Surface covered by deep lateritic soil, where a "cerradocaatinga" vegetation has established itself, with scrub savanna characteristics. On this surface remains of a lateritic duricrust occur.

B. One karstic unit, formed by the exhumation of small hills between altitudes of $750 \mathrm{~m}$ and $615 \mathrm{~m}$, with a vegetation of pastures and remains of a dry thicket, sub caducifolia, with elements of "caatinga".

C. The fluvio-karst of Peruaçu, with its blind valleys, canyons, and subterranean paths, with perennial vegetation predominating.

D. A sinkhole land unit between the altitudes of $750 \mathrm{~m}$ and $615 \mathrm{~m}$, covered with artificial pastures and dry forest "mata seca". 
E. A rocky escarpment, covered by a field of lapiés, between the altitudes of $700 \mathrm{~m}$ and $500 \mathrm{~m}$ where some cactuses are established.

F. The São Franciscan depression characterized by its fluvial plains, between altitudes of $500 \mathrm{~m}$ and $400 \mathrm{~m}$, with its dissolution sinkholes, along the São Francisco River $(440 \mathrm{~m})$ and its floodplains with their channel sands and temporary lagoons, between the altitudes of $440 \mathrm{~m}$ and $438 \mathrm{~m}$. Over the alluvial soils established originally a caducifolia forest, today this has been partially replaced by pastures and agricultural enterprises.

\section{Farming - cattle breeding scenario.}

A TM-Landsat image, (WRS 219-70, 1997, Fig. 1), has been produced with a multispectral false-color composition (bands 4, 5 and 3 - RGB) and a panchromatic band 4 enhancement, at a scale of 1:1,000,000. This provides the best visual separation of the main geomorphological regions, compatible with the scale. The image has made it possible to delineate three geomorphologic units and their respective land use from the highest lands to the plain:

I. Covered karst, represented by the remains of the Cretaceous surface, where duricrust and sandy soils derived from silicified sandstones dominate, preserves traditional extensive cattle breeding ( 1 animal per ha.). On the South American Surface, over lateritic soils, great areas of savanna were replaced with artificial pastures. This allowed the implementation of large cattle farms, directly irrigated from the Rio Peruaçu and its tributaries.

II. In the karstic region, only the declivities that link the South American Surface to the karst and to the region of large sinkhole plain allowed an extension of the areas of pasture. In the fluvio-karst, outcropping limestone, and in the rocky escarpment, towards the São Francisco plains, farming and cattle breeding activities are insignificant.

III. In the vast valley of the San Francisco River a development of great agricultural undertakings began, together with the establishment of cattle ranches. The semi-arid climate, a limiting factor for agriculture in the past, was kept under control by great irrigation projects, using ground water irrigated by central pivot sprinklers and distribution through channels. The Landsat image (Fig.1) clearly illustrates these two irrigation techniques.

\section{The impacts of farming and cattle breeding over karst (table 1)}

The environmental impact on the region studied have their origins in the 17th century, when the people of the region, the Portuguese and the "paulistas bandeirantes" (defending the crown) conquered the back-country along the São Francisco river to secure navigation privileges. The vegetation clearance began, and continues to the present, together with installation of open-cut coal mines, to obtain space for farming and cattle breeding. 


\section{GEOLOGICAL, GEOMORPHOLOGICAL AND LAND USE DATA}

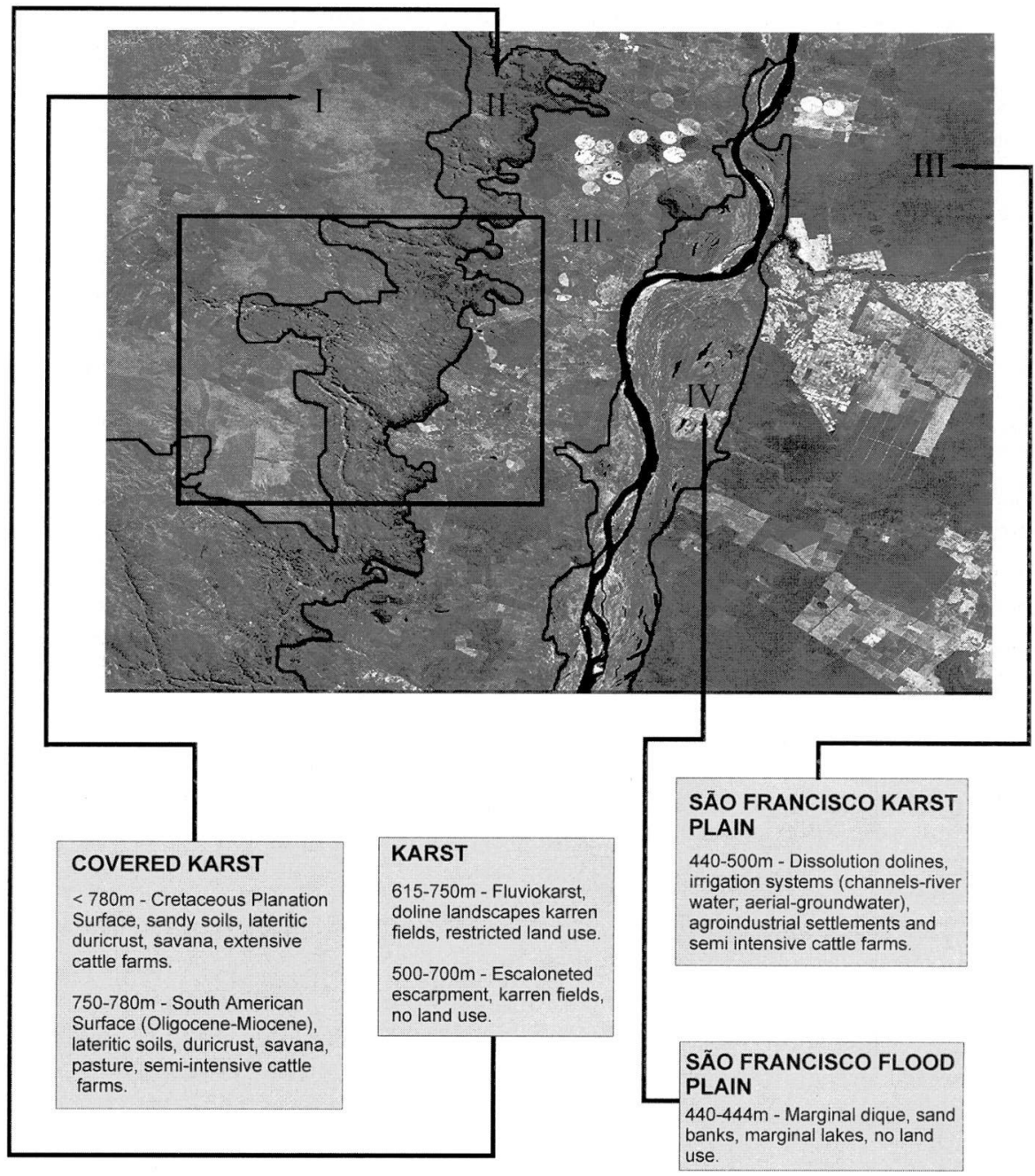

Fig. 1 - Landsat image of the examined area.

\begin{tabular}{|l|l|l|}
\hline \multicolumn{3}{|l|}{ Main Agriculture Products in Minas Gerais - North Region (1996) } \\
\hline JANUARIA & ITACARAMBI & MONTE AZUL \\
\hline Soybeans $(4000 \mathrm{ha})$ & Beans $(4100 \mathrm{ha})$ & Cotton $(5000 \mathrm{ha})$ \\
\hline Beans $(4100 \mathrm{ha})$ & Corn $(2720 \mathrm{ha})$ & Rice $(2000 \mathrm{ha})$ \\
\hline Manioca $(2500 \mathrm{ha})$ & & Corn $(5000 \mathrm{ha})$ \\
\hline
\end{tabular}

Table 1 - Table of land uses, in the North Region of Minas Gerais, with areas of land involved. 
The ease of obtaining karstic waters and the utilization of irrigation systems through the central pivot sprinkler, transformed the area at the end of the 1970's The traditional systems (extensive cattle breeding and cotton cultivation) were transformed into semi intensive cattle breeding, great mechanical fieldwork and farming and cattle breeding projects, as well as small-holdings with their familiar diverse farming. The impact caused by changes in economic structure and management leads, as geographer Dr. Maria Aparecida dos Santos Tubaldini ${ }^{1}$ points out, to the small farmer selling their small-holdings or gleba. These have been transformed into medium or large properties.

Today, the outcome of this land use change some implemented with no previous environmental impact research, has led to bankruptcy for some landowners. They have exhausted the karstic wells by water pumping, and no study has been made of the rate of natural replenishing of these wells. This has resulted in salinization and compaction of the soils. The hydro-geologist, Mr. Fernando Jardim², regrets the lack of research done on the behavior and dimension of the karst underground water, as well as the hydraulic flow of the São Francisco river and tributaries.

Another impact of the karstic underground waters that has yet to be studied is that caused by water pollution by toxic compounds and bacteria. We live in a period of global warming, which could also be catastrophic to the region.

Karstic land use in the intertropical region, with farming and cattle breeding dominant (e.g. the valley of São Francisco) should be periodically monitored so that prompt corrective measures can be taken to prevent irreversible damage.

The creation of APA - Peruaçu (an area of environmental protection for the basin of the Peruaçu river) by the Federal government in 1992, was received with great optimism by conservationists and regional inhabitants. However there are still no economic and ecological zoning definitions, which disadvantages the ongoing management of the APA.

\section{REFERENCES}

CAMPOS A. B., KOHLER H. C. and FANTINEL L. M., 1992. Influencias litoestruturais nos paredoes de lapiezamento sobre rochas carbonáticas do Grupo Bambuí na regiao de Itacarambi/MG. Anais III Gongr. ABEQUA, Belo Horizonte, pp.3-12.

DARDENNE M. A., 1981. Os Grupos Pananoá e Bambuí na Faixa dobrada de Brasília. Salvador, SBG, pp. 140-155.

EPAMIG, EMBRAPA and RURALMINAS, 1976. Levantamento de Reconhecimento com detalhe dos solos do Distrito Agroindustrial de Jaíba-Minas Gerais. Belo Horizonte, EPAMIG, Bol. 54.

KARMANN I. and SANCHEZ L. E., 1972. Distribuicao das rochas carbonáticas e províncias espeleológicas do Brazil. Sao Paulo, Espeleotema 13: 105-167.

PILO L. B., 1989. A morfologia cárstica do baixo curso do Rio Peruacu, Januária Itacarambi, Belo Horizonte, IGC-UFMG, pp. 11-79.

\footnotetext{
${ }^{1}$ pers. comm.

2 pers. comm.
} 